\title{
Is big brother more at risk than little sister? The sibling factor in online risk and opportunity
}

\author{
Accepted version, as published in:
}

Ólafsson, K., Green, L., \& Staksrud, E. (2017). Is big brother more at risk than little sister?

The sibling factor in online risk and opportunity. New Media \& Society, s. 1-20. doi: $10.1177 / 1461444817691531$

\section{Kjartan Ólafsson ${ }^{1}$ \\ Lelia Green ${ }^{2}$ \\ Elisabeth Staksrud ${ }^{3}$}

\begin{abstract}
This article uses data from the 25,142-child study EU Kids Online to investigate the impact of sibling status on a child's experience of online risk and opportunities. In general, the effects associated with having a sibling appear to be comparatively small. The presence of older siblings slightly increases use and skills, while younger siblings are associated with slight reductions. These dynamics are particularly visible in the use of social networking sites. Older siblings have the effect of increasing the range and number of online activities pursued by their younger siblings. Patterns around concerning exposure to risk and possible harm are not straightforward but younger children with an older sibling are not at an increased risk. Where younger aged children have even younger siblings, this is associated with a slight reduction in risk, whereas older-aged children with a younger sibling, and only children, appear to experience slight increases in risk.
\end{abstract}

\section{Keywords}

Brother, effects, family, impact, Internet, online opportunities, online risk, siblings, sister

\section{Introduction}

Today's children live much of their lives online. A rich body of research has looked at how peer-relationships influence how children go online, especially in relation to cyberbullying. Less attention has been paid, however, to the question of sibling influence on online risk

\footnotetext{
${ }^{1}$ Haskolinn a Akureyri, Iceland

2 Edith Cowan University, Australia

3 Universitetet i Oslo Det humanistiske fakultet, Norway

${ }^{4}$ All authors contributed equally to this article.
} 
and opportunity for children. It is the aim of this article to address this aspect of children's (aged 9-16) online experience.

A sibling is (in most cases) both a peer and an intimate, offering a continuous relationship for the child throughout their everyday life. ${ }^{5}$ In fact, viewed across all life stages, the longest lasting and most enduring relationship an individual can develop is with a sibling. This close connection plays a potentially dynamic role in a child's social development. For example, siblings offer an opportunity for social activity when there are no friends (or parents) present (Milevsky, 2011), relating positively to the promotion of resilience in children (Sanders, 2004).

Resilience is intrinsically linked to the concept of risk - some object or event that might cause damage or danger, loss, harm or hazard. The kinds of risks children can encounter online include, but are not limited to, excessive Internet use (Šmahel et al., 2012), cyberbullying, access to inappropriate/adult materials, privacy risks and meeting online a stranger not previously known through in-person social contacts (see, for example, Livingstone et al., 2011a: 45-101). When children experience online risks, such as these, it might lead to harm, but it might also lead to coping, adaptation and the development of resilience. As defined by Jenson and Fraser (2016), 'Resilience is characterized by successful adaptation in the presence of risk or adversity' (p. 13). Notably, Jenson and Fraser (2016: 14) identify a range of protective factors that help people cope with risk. These include 'Caring relationships with siblings' as the second most important of six identified 'Interpersonal and Social Factors', following on from 'Attachment to parents'.

The complex concept of risk, and its potential relationship to pro-social outcomes such as the development of resilience, has prompted a recent research emphasis upon peer-group relations and the ways in which shared media use may facilitate and impact upon exposure to risk. Peers continue to be an important priority for new media studies around risk and opportunity, benefit and harm, when considering young people's online engagements. Thus, there is a body of research relating the influence of peers to the experience and impact of online risk (see, for instance, Coyne et al., 2006; Kaare et al., 2007; Livingstone, 2008; Mascheroni et al., 2015; Staksrud et al. 2013; Suess et al., 1998; Suoninen, 2001). No equivalent attention, however, has been paid to siblings. This article addresses that gap.

'The family' - family constellations, domestication and everyday practices in the home - has been at the core of research into children's media consumption, yet the impact of sibling relationships upon how young people develop personal styles of media use and communication practices has been under-emphasised in the research literature. It is reasonable to hypothesise that sibling relationships have a critical influence upon children's behaviour and are also a focus of parental concern and intervention. Many parents stress to their older children that the media they consume (say at 14-16 years old) is unsuitable for their younger siblings (say 9-11 years old) (Green and Haddon, 2015: 19). If asked, older siblings often state positive, protective attitudes towards supporting their younger brothers' and sisters' online experiences (Farrugia and Haddon, 2014). Qualitative research demonstrates that, in terms of media and communication practices in multi-child families, many activities are shared and negotiated with siblings (Farrugia and Haddon, 2014; Green and Haddon, 2015; Kaare et al., 2007). Such shared experiences include being

${ }^{5}$ The authors recognise how some children might have siblings with an age gap that is substantial, thus not constituting a peer. The authors also recognise how some siblings might not, for various reasons, share an everyday life in a practical sense, but belong to different households. However, these exceptions are controlled for in the following analysis, as explained in the section on methodology. 
generally subject to the same parental mediation principles. This is true even given the potential for parents to treat each of their children differently due to differences in, for example, age, gender, personality, social status, access to various types of media and communication technology and content, and leisure versus duty constraints upon the distribution of children's time - to mention some aspects of this complex issue. Indeed, as Meunier et al. (2013) argue, 'sensitive parenting, a dimension of parenting shown to be important in children's social development, is defined as the parent's [singular in original] ability to respond appropriately to the idiosyncratic needs of individual children' (p. 1596). A further reasonable hypothesis is that the skills and competencies of older children can have both positive and negative influences upon the digital behaviours, opportunities and aspirations of their younger siblings: sometimes even concurrently.

In terms of media usage in general and experiences of online risks and opportunities in particular, differences between children have been found to influence what kinds of experiences children have, how much they are at risk of harm, what coping mechanisms they employ and how resilient they are (Duerager and Livingstone, 2012; Vandoninck et al., 2011). However, the effect of sibling constellation on digital use, mediation and risk experience is yet to be subject to rigorous research. This article aims to fill this research gap by examining how a child's sibling constellation influences - or not - the ways in which they use the Internet, what opportunities they are afforded and how much risk they experience. The research reported here uses the power of matched interviews with children (aged 9-16) and the parent most involved with their Internet use (i.e. 25,104 interviews each with parents and children, separately) from a representative survey across 25 European nations conducted in 2010: the so-called 'EU Kids Online' survey (Livingstone et al., 2011a).

This quasi-control investigation, examining the experiences of children in families with different sibling constellations, is one way to interrogate the possible influences of an older sibling upon younger members of a family. Although data collection was in 2010, and might thus be better suited to longitudinal investigations, it remains the most powerful available to researchers. It has only recently been interrogated in terms of these research issues, in response to the lack of other robust empirical work addressing the influence of siblings upon children's experience of online risk.

\section{Previous research on sibling constellation}

\section{Social competence and conflict}

Caverly (2006) found that when children were rated as aggressive by their teachers, they were more likely to have high conflict in their sibling relationships when compared with children rated as less aggressive by teachers, who had low levels of sibling conflict. In a seminal US study with 73 children (Minnett et al., 1983), 7- to 8-year-olds were videotaped when interacting with a sibling in cooperative, competitive and neutral situations. Concluding that sibling status and an agenda-focused upbringing were critical to a child's experience of relating to their sibling/s, the researchers indicated that birth order had a significant impact. First-born 7- to 8-year-olds, and girls, were more likely to relate positively to their siblings, offering praise and trying to teach skills. Second-born children were more likely to indicate that they were having fun and to be self-deprecating in their interactions. Where two siblings were comparatively close in age, they were more likely to exhibit some aggressive behaviour. Positive support and affection characterised interactions between siblings with a wider age gap. Where children were interacting with same-sex siblings, there was an increased chance of dominant behaviour, aggression and cheating than was the case with girl and boy sibling pairs. These factors indicate that 
sibling order and the gender of siblings may impact upon sibling-facilitated experiences with new media.

Howe et al. (2016) investigated sibling teaching strategies in young children in a longitudinal framework. They observed inter-sibling teaching exchanges of 39 middle-class sibling pairs at two time points: T1, where the older sibling averaged 4.4 years and the younger one 2.4 years; and T2, with older siblings at 6.3 and younger ones at 4.4 years old. The research indicates that both the older and younger child in the pair may request instruction from their sibling with the incidence of younger siblings teaching older ones increasing at T2. Findings highlighted 'the bidirectional nature of teacher-learner interactions [...] indicating that the sibling relationship is a rich context for children's learning and development' (Howe et al., 2016: 1832). The current article explores the sibling relationship in terms of online activities and exposure both to digital risks and opportunities for learning.

\section{Skills}

Related to development of skills, often thought of as an important factor for future educational opportunities and welfare, sibling constellation research from the United States indicates that children's unequal access to technology within family settings is not the exception, but the norm. A study by Robinson and Schulz (2013) examined interfamily negotiations around time online ('net time'), demonstrating the existence of bargaining practices within families related both to the purpose of the online activity and to the level of Internet service enjoyed by the household, which was characterised as being either 'highly wired, partially wired, [or] unwired' (p. 542). Their study examined 'how social processes of negotiation, competition, and cooperation within the family influences ICT use' (Robinson and Schulz, 2013: 546). Robinson and Schulz found that the most careful bargaining occurred in families with limited resources: the partially wired households. Here, online access reflected '(1) the amount of household net time the user could legitimately claim as a "fair share" and (2) the kinds of tasks that the user needs to accomplish' (Robinson and Schulz, 2013: 553). In unwired families, the negotiation takes place around freeing up the time or transport resources required to permit access to information and communication technologies (ICTs) away from home. Thus, Belinda [says]: "Sometimes my sister will get my little brothers ready in the morning without me so that I can get to school early and use the computers in Mrs. Schrempf's room", while "Gino must ask his brother to "cover him" at work: "If I want to use the lab I have to ask my brother to take my shift" (both examples from Robinson and Schulz, 2013: 554). Clearly, in these circumstances, siblings are key enablers of Internet time.

Alongside research such as this, which charts the negotiations required by children who seek to spend time online, are findings such as those of Livingstone et al. (2011a) which establish that 'more use facilitates digital literacy and safety skills' (p. 5) even though 'more use of the internet seems to go hand in hand with a higher likelihood of being exposed to one or more of the risk factors' (p. 139). From this, we can predict that children without siblings (those who are an 'only child') might get more online time but lack the benefit of sibling support, interaction and teaching.

Other research on sibling constellation and relationships at a more general level have found a significant effect between sibling constellation status, the quality of sibling relationships, and children's welfare and behaviour (see, for example, Howe and Recchia, 2014.) As a consequence of prior research, we hypothesise that having a sibling, and the particular sibling constellation, influences a child's digital welfare, including how much and what kinds of online risks a child might encounter, what skills he or she will develop and 
how well that child might cope with digital risk experiences. Specifically, we asked the following research questions using the EU Kids Online database (RQ):

RQ1. Whether and how sibling status influences children's use, activities and skills online.

RQ2. Whether and how sibling status influences children's experiences with online risks and risk of harm.

RQ3. Whether and how sibling status can predict online opportunities and risks.

\section{Method}

\section{Sample and procedure}

A random stratified sample of approximately 1000 Internet-using children aged between 9-16 years was interviewed in each of 25 European countries (Austria, Belgium, Bulgaria, Cyprus, the Czech Republic, Denmark, Estonia, Finland, France, Germany, Greece, Hungary, Ireland, Italy, Lithuania, the Netherlands, Norway, Poland, Portugal, Romania, Slovenia, Spain, Sweden, Turkey and the United Kingdom). These countries were selected to represent the economic, geographic and cultural diversity of European Union countries (including all large and most small countries in the EU) plus Norway (the earliest adopter of the Internet in Europe) and Turkey (a culturally diverse, late-adopting, aspiring member of the EU).

The total sample size for children was 25,142. Additionally, one parent (whichever knew most about the child's Internet use) was interviewed. In-depth interviews permitted careful exploration of the contexts of children's Internet use as well as a detailed account of the nature, skills and social mediations that characterise that use. The questionnaire, translated and back-translated from English into 24 languages, underwent cognitive testing and pilot testing to aid completion by children. Interviews took place during spring and summer 2010 in children's homes, conducted face-to-face but with private questionnaire completion (computer-assisted or pen-and-paper) for sensitive questions related to risk. Average interview time per child was 45 minutes (Livingstone et al., 2011a, 2011b).

\section{On siblings and sibling patterns in the EU Kids Online data}

The questionnaire was not designed specifically to investigate the characteristics of how siblings might facilitate children's exposure to online risks and opportunities. Such analysis has therefore been conducted as part of secondary research with this database. It is worth noting that the primary focus of the data collection was always upon the child in the household aged between 9 and 16 years with the most recent (or next, depending upon the country) birthday. Household data were originally collected for demographic purposes and in the process of selecting respondents, rather than as a result of a research query into sibling status in its own right. These factors limit some aspects of the analysis.

The children in the household are not necessarily (biological) siblings and the questionnaire does not provide information on how the children are related to each other. Also, we do not know the total number of children in the household. What the data record is how many children there are aged 9-16 years, and whether there are children aged 0-8 and 17+ years, but not how many children there are in the age group below 9 and above 16 years. The first step in our analysis was to create a set of new variables where the available information on the age of children in the household was represented by an alphabetical code in the following way:

$$
\begin{aligned}
& \mathrm{A}=\text { Child (or children) aged } 0-4 \text { is (are) present in the household } \\
& \mathrm{B}=\text { Child (or children) aged } 5-8 \text { is (are) present in the household } \\
& \mathrm{C}=\text { Child aged } 9
\end{aligned}
$$


$\mathrm{D}=$ Child aged 10

$\mathrm{E}=$ Child aged 11

$\mathrm{F}=$ Child aged 12

$\mathrm{G}=$ Child aged 13

$\mathrm{H}=$ Child aged 14

$\mathrm{I}=$ Child aged 15

$\mathrm{J}=$ Child aged 16

$\mathrm{K}=$ Child (or children) aged $17+$ is (are) present in the household

These variables were then combined to capture the age combinations of children in the household. Taking as an example the case of a household where there is one child aged 58 years and another aged 10 years, the code would be 'BD'. For a household where there is one child aged 9, another aged 11 and a third aged 13 years, the code would be 'CEG'. Through this approach, we could collect into a single variable the full details of sibling compositions in the data. The next step was to simplify this information again, taking into consideration the relative age difference between the children in the household. The aim was to create three dummy variables. One to indicate that there is a younger child (or children) in the household, a second to indicate the presence of a child (or children) of similar age and a third to indicate the presence of an older child (or children) in the household. For children of each age, the definition of what constitutes a younger, same age or an older child is varied so that children are considered to be of the same age if they are less than 3 years apart. According to this scheme, a 9-year-old is considered to have an older child in the household if there is another child aged 12 or more. For a 12 -year-old respondent, however, if there is another child in the household, that child is classified as of 'similar age' until they are 15 or over.

We used these data to create a new categorical variable with seven categories for the seven main types of sibling combinations. Table 1 shows the un-weighted number and percentage of respondents that fall into each category.

When looking at the findings, it is important to remember that there is a correlation between age and sibling status. The way we measure sibling status means that the older respondents might have older siblings but these would be 18 years or older,

Table 1. Un-weighted number and percentage of respondents in each sibling category.

\begin{tabular}{lll}
\hline & Frequency & Percent \\
\hline Only child & 9605 & 38.2 \\
Has younger siblings & 7064 & 28.1 \\
Has siblings of similar age and younger & 1486 & 5.9 \\
Has siblings of similar age & 3189 & 12.7 \\
Has siblings of similar age and older & 382 & 1.5 \\
Has older siblings & 2688 & 10.7 \\
Has both younger and older siblings & 728 & 2.9 \\
Total & 25,142 & 100 \\
\hline
\end{tabular}

and therefore, if they live at home, they are counted as other adults in the demographic data and not visible to this sibling-based analysis of children in the household (Table 2). On the other hand, if these older siblings have moved away, they are not counted at all. For this reason, the cells in the tables for 15- to 16-year-olds who have older siblings generally tend towards empty. In a way, this also means that it is not very meaningful to look at the figures for 'all children' as the group of respondents classified as having an older sibling will by default have no respondents aged 15-16 years. However, the 'all' figures (other than these) have been included in the tables for the sake of completeness. Although we acknowledge these limitations, the categories made visible through this 
analysis offer the opportunity to investigate patterns common to sibling constellation and online risk, opportunities and coping strategies. For a description of other key variables, see Livingstone et al. (2012).

\section{Findings and discussion}

\section{Sibling differences in use}

First we look at results related to opportunities (here understood as daily use, number of activities and skills, cf. RQ1) and begin with the question of access, measured here as daily Internet use (see Table 3). The results indicate that the presence of a similar age or older sibling increases the chance that a child in Europe will use the Internet daily. For the 9- to 10 -year-old age group, having a sibling of similar age or older is associated with a $52 \%$ incidence of daily use, compared with a child of the same age with only younger siblings (a $38 \%$ chance of daily use). In both the 11 - to 12-year-old and 13- to 14-year-old age groups, having an older age sibling is associated with the greatest likelihood in that cohort of the child using the Internet every day, while once children have reached the oldest age group in the research (15-16 years), the only situation associated with a diminution of likelihood of daily Internet use is having a sibling of similar age and younger (which might imply that the child has some caregiver duties, or is less able to win negotiations over access with a closer age sibling than with a younger sibling). Interestingly, once an only child passes the secondary school threshold, often in the 11-12 age range, their likelihood of going online daily is second only to that of children with an older sibling. It is tempting to speculate that the absence of other children in the household might prompt greater use of online connectivity.

These data demonstrate that, in every cohort related to a sibling constellation, children between 9-16 spend more time online each day in direct relationship to their

Table 2. Coding scheme for sibling status versus age.

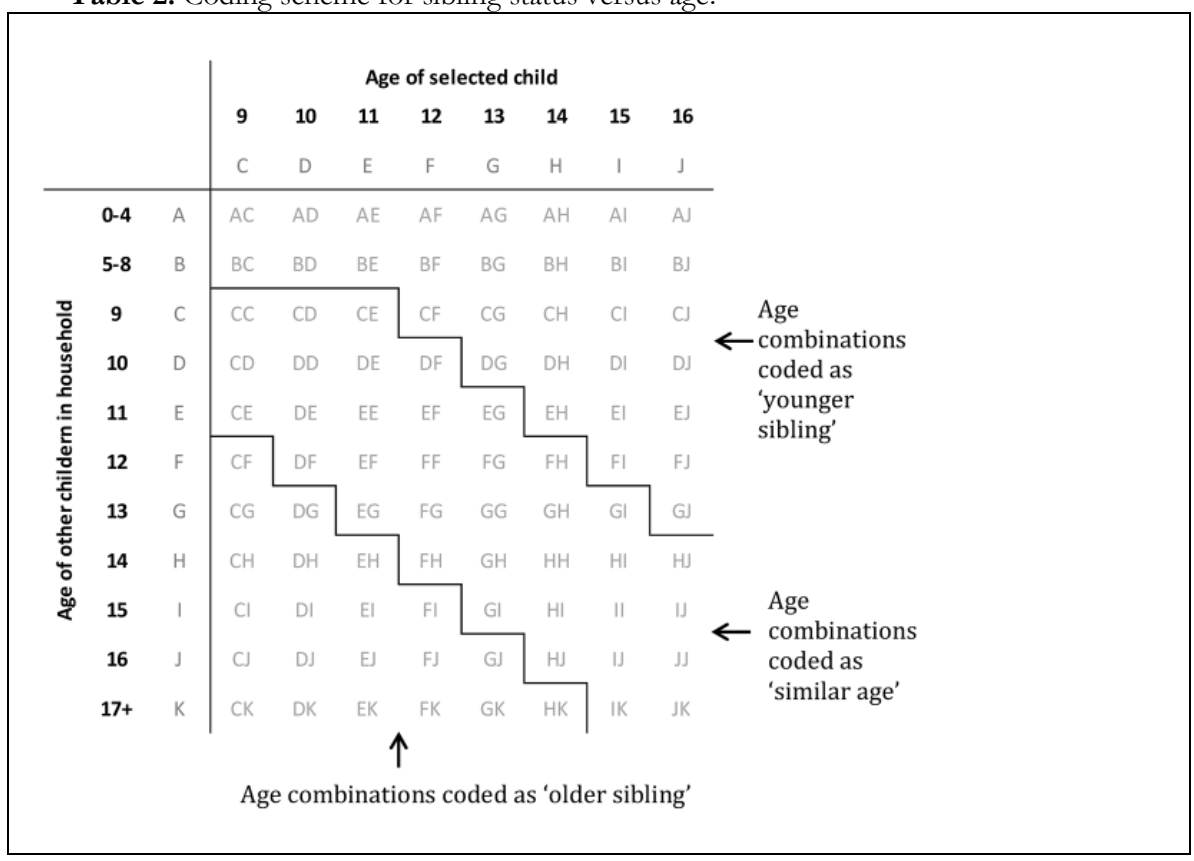


Table 3. Percentage of children who use the Internet daily in relation to the age of their sibling.

\begin{tabular}{llllllll}
\hline $\begin{array}{l}\text { \% Use of } \\
\text { Internet daily }\end{array}$ & $\begin{array}{l}\text { Only } \\
\text { child }\end{array}$ & $\begin{array}{l}\text { Has } \\
\text { younger } \\
\text { sibling/s }\end{array}$ & $\begin{array}{l}\text { Has siblings of } \\
\text { similar age and } \\
\text { younger }\end{array}$ & $\begin{array}{l}\text { Has } \\
\text { sibling/s of } \\
\text { similar age }\end{array}$ & $\begin{array}{l}\text { Has siblings of } \\
\text { similar age and } \\
\text { older }\end{array}$ & $\begin{array}{l}\text { Has older } \\
\text { sibling/s }\end{array}$ & $\begin{array}{l}\text { Has both } \\
\text { younger and } \\
\text { older siblings }\end{array}$ \\
\hline Alla $^{\text {sinnny }}$ & 67 & 62 & 67 & 73 & 62 & 63 & 55 \\
$\Delta P_{(95 \%)}$ & 0.9 & 1.1 & 2.4 & 1.5 & 4.9 & 1.8 & 3.6 \\
$9-10$ years & 40 & 38 & 47 & 44 & 52 & 45 & 51 \\
$\Delta P_{(95 \%)}$ & 2.0 & 2.1 & 7.4 & 5.2 & 10.2 & 3.1 & 5.8 \\
$11-12$ years & 63 & 58 & 55 & 60 & 59 & 68 & 53 \\
$\Delta P_{(95 \%)}$ & 2.1 & 2.3 & 5.1 & 3.6 & 7.4 & 3.0 & 6.0 \\
$13-14$ years & 78 & 74 & 73 & 77 & 75 & 81 & 63 \\
$\Delta P_{(95 \%)}$ & 1.7 & 2.1 & 4.3 & 3.0 & 7.9 & 2.8 & 7.1 \\
$15-16$ years & 85 & 84 & 77 & 84 & & & \\
$\Delta P_{(95 \%)}$ & 1.3 & 1.8 & 3.6 & 1.9 & & & \\
\hline
\end{tabular}

${ }^{a}$ The figures for 'all children' may have limited relevance since older children's older siblings are not captured in the data. Even so, they have been included for the sake of completeness.

age: the older the child, the more time they are likely to spend online (Table 4). This generality is so strong that the age-of-child factor tends to dominate any difference that might be perceived around the impact of sibling constellation.

Table 4. Estimated time spent online each day (minutes).

\begin{tabular}{llllllll}
\hline $\begin{array}{l}\text { Average } \\
\text { minutes online }\end{array}$ & $\begin{array}{l}\text { Only } \\
\text { child }\end{array}$ & $\begin{array}{l}\text { Has } \\
\text { younger } \\
\text { sibling/s }\end{array}$ & $\begin{array}{l}\text { Has siblings of } \\
\text { similar age and } \\
\text { younger }\end{array}$ & $\begin{array}{l}\text { Has sibling/s similar age } \\
\text { of siblings } \\
\text { of similar age } \\
\text { and older }\end{array}$ & $\begin{array}{l}\text { Has older } \\
\text { sibling/s }\end{array}$ & $\begin{array}{l}\text { Has both } \\
\text { younger and } \\
\text { older siblings }\end{array}$ \\
\hline Alla & 93 & 88 & 91 & 96 & 69 & 75 & 67 \\
$\Delta_{(95 \%)}$ & 1.4 & 1.5 & 2.6 & 2.0 & 3.8 & 1.8 & 2.7 \\
$9-10$ years & 60 & 54 & 58 & 55 & 53 & 60 & 63 \\
$\Delta_{(95 \%)}$ & 1.8 & 2.0 & 5.1 & 3.5 & 4.9 & 2.3 & 3.9 \\
$11-12$ years & 77 & 73 & 72 & 77 & 72 & 76 & 64 \\
$\Delta_{(95 \%)}$ & 2.4 & 2.5 & 4.2 & 3.3 & 5.8 & 3.0 & 4.4 \\
$13-14$ years & 104 & 95 & 95 & 95 & 82 & 100 & 74 \\
$\Delta_{(95 \%)}$ & 2.9 & 2.5 & 4.7 & 3.4 & 8.0 & 4.5 & 5.7 \\
$15-16$ years & 120 & 118 & 105 & 120 & & & \\
$\Delta_{(95 \%)}$ & 2.6 & 3.1 & 4.5 & 3.6 & & & \\
\hline
\end{tabular}

aSee previous comment on interpretation of the 'all' figure.

Table 5. Percentage of children who have their own personal computer (PC) or laptop in relation to the age of their sibling.

\begin{tabular}{llllllll}
\hline $\begin{array}{l}\text { \% Has own } \\
\text { PC or laptop }\end{array}$ & $\begin{array}{l}\text { Only } \\
\text { child }\end{array}$ & $\begin{array}{l}\text { Has } \\
\text { younger } \\
\text { sibling/s }\end{array}$ & $\begin{array}{l}\text { Has siblings } \\
\text { of similar age } \\
\text { and younger }\end{array}$ & $\begin{array}{l}\text { Has } \\
\text { sibling/s of } \\
\text { similar age }\end{array}$ & $\begin{array}{l}\text { Has siblings } \\
\text { of similar } \\
\text { age and } \\
\text { older }\end{array}$ & $\begin{array}{l}\text { Has older } \\
\text { sibling/s }\end{array}$ & $\begin{array}{l}\text { Has both } \\
\text { younger and } \\
\text { older } \\
\text { siblings }\end{array}$ \\
\hline Alla & 57 & 50 & 46 & 54 & 37 & 42 & 33 \\
$\Delta P_{(95 \%)}$ & 1.0 & 1.2 & 2.5 & 1.7 & 4.8 & 1.9 & 3.4 \\
$9-10$ years & 35 & 30 & 28 & 34 & 23 & 30 & 32 \\
$\Delta P_{(95 \%)}$ & 1.9 & 2.0 & 6.7 & 5.0 & 8.6 & 2.8 & 5.4 \\
$11-12$ years & 51 & 46 & 38 & 44 & 37 & 44 & 39 \\
$\Delta P_{(95 \%)}$ & 2.2 & 2.4 & 5.0 & 3.7 & 7.2 & 3.2 & 5.9 \\
$13-14$ years & 63 & 52 & 44 & 52 & 52 & 59 & 26 \\
$\Delta P_{(95 \%)}$ & 2.0 & 2.4 & 4.8 & 3.6 & 9.1 & 3.6 & 6.5 \\
$15-16$ years & 73 & 67 & 56 & 66 & & & \\
$\Delta P_{(95 \%)}$ & 1.7 & 2.4 & 4.2 & 2.5 & & & \\
\hline
\end{tabular}

a See previous comment on interpretation of the 'all' figure. 
Private use of devices also increases with age across the sibling cohorts, apart from those interviewees with both younger and older siblings. This might reflect the additional budgetary pressures in these households. Indeed, it is notable that only children are more likely than other children of a similar age to have their own laptop, and the more children there are in a household, the more likely it is that resources will be stretched. Even so, it is interesting to see that $39 \%$ of children aged 11-12 years with both younger and older siblings have a laptop compared with $26 \%$ of 13 - to 14-year-olds from the same sibling constellation (Table 5).

\section{Sibling differences in activities}

Table 6 shows the percentage of children having their own personal social network site (SNS) profile. Again, the results indicate the strong association of this online behaviour with age, without painting as clear a picture of this activity in relation to sibling constellation. The data demonstrate a general tendency for children with siblings

Table 6. Percentage of children who have their own social networking site (SNS) profile in relation to the age of their siblings.

\begin{tabular}{|c|c|c|c|c|c|c|c|}
\hline $\begin{array}{l}\% \text { With } \\
\text { profile on } \\
\text { SNS }\end{array}$ & $\begin{array}{l}\text { Only } \\
\text { child }\end{array}$ & $\begin{array}{l}\text { Has } \\
\text { younger } \\
\text { sibling/s }\end{array}$ & $\begin{array}{l}\text { Has siblings of } \\
\text { similar age and } \\
\text { younger }\end{array}$ & $\begin{array}{l}\text { Has sibling/s } \\
\text { of similar age }\end{array}$ & $\begin{array}{l}\text { Has siblings } \\
\text { of similar age } \\
\text { and older }\end{array}$ & $\begin{array}{l}\text { Has older } \\
\text { sibling/s }\end{array}$ & $\begin{array}{l}\text { Has both } \\
\text { younger and } \\
\text { older siblings }\end{array}$ \\
\hline $\mathrm{All}^{\mathrm{a}}$ & 60 & 59 & 64 & 66 & 57 & 49 & 45 \\
\hline$\Delta P_{(95 \%)}$ & 1.0 & 1.1 & 2.4 & 1.6 & 5.0 & 1.9 & 3.6 \\
\hline $9-10$ years & 25 & 24 & 22 & 24 & 36 & 29 & 30 \\
\hline$\Delta P_{(95 \%)}$ & 1.7 & 1.8 & 6.1 & 4.5 & 9.8 & 2.8 & 5.4 \\
\hline $11-12$ years & 52 & 45 & 43 & 48 & 57 & 55 & 44 \\
\hline$\Delta P_{(95 \%)}$ & 2.2 & 2.4 & 5.1 & 3.7 & 7.4 & 3.2 & 6.0 \\
\hline $13-14$ years & 74 & 70 & 72 & 75 & 83 & 74 & 65 \\
\hline$\Delta P_{(95 \%)}$ & 1.8 & 2.2 & 4.4 & 3.1 & 6.9 & 3.2 & 7.0 \\
\hline $15-16$ years & 82 & 84 & 79 & 83 & & & \\
\hline$\Delta P_{(95 \%)}$ & 1.4 & 1.8 & 3.5 & 2.0 & & & \\
\hline
\end{tabular}

${ }^{a}$ See previous comment on interpretation of the 'all' figure.

of a similar age, and children with siblings of both a similar age and older, and children with older siblings, to be more likely to have a SNS profile, but this is not universally or unambiguously the case, so it is more of an indication for further investigation than a finding. Even so, there is some indication that children in the 13- to 14-year-old range (the age group when some of the largest SNSs first officially allow children to have their own profile), who have younger siblings, or siblings of a similar age and younger, are somewhat less likely than children with same age and older siblings to have an SNS profile. This might reflect parents' desire to delay the introduction of SNS activity into the home for as long as possible, given that younger children are more likely to want to have their own SNS profile once an older sibling is active on SNSs.

The number of online activities a child says that they can do is sometimes used as a proxy measure of skills, benefit and opportunity. Like risk, this is related to time spent online, both in terms of the number of years (as in comparatively early adopters) and in terms of the time spent online per day or week. Children were presented with a list of 17 online activities - such as schoolwork, watching video clips, playing games using the computer and so on (see Livingstone et al. (2011a: 34) for this list) and asked to indicate which of these activities they had participated in over the past month. Once again it is age that correlates with a greater range of activities, rather than sibling constellation. There is some indication, however, that having an 
older sibling is associated with greater skill development in the 9- to 10-year-old and 11- to 12year-old age groups (measured as range of activities). It is possible that the peer effect becomes more important by the time children are 13-14, and thus, children in this age range are as likely to be shown skills by peers in their social circle as they are by more experienced, older siblings. The comparatively high number of activities associated with only children may be a counter to this general rule, but it may also indicate that the child has less competition for the time of adults in the household, greater incentive and opportunity to go online, and access to greater financial (and possibly educational) resources (Table 7).

\section{Sibling differences in skills}

Whereas the previous list examined children's general online activities over the month preceding the survey, literacy and safety skills examined children's competencies around

Table 7. Number of online activities.

\begin{tabular}{|c|c|c|c|c|c|c|c|}
\hline $\begin{array}{l}\text { Average } \\
\text { number of } \\
\text { activities }\end{array}$ & $\begin{array}{l}\text { Only } \\
\text { child }\end{array}$ & $\begin{array}{l}\text { Has } \\
\text { younger } \\
\text { sibling/s }\end{array}$ & $\begin{array}{l}\text { Has similar age } \\
\text { and younger } \\
\text { siblings }\end{array}$ & $\begin{array}{l}\text { Has similar } \\
\text { age } \\
\text { sibling/s }\end{array}$ & $\begin{array}{l}\text { Has similar } \\
\text { age and older } \\
\text { siblings }\end{array}$ & $\begin{array}{l}\text { Has older } \\
\text { sibling/s }\end{array}$ & $\begin{array}{l}\text { Has both } \\
\text { younger and } \\
\text { older siblings }\end{array}$ \\
\hline Alla & 7.5 & 7.2 & 7.3 & 7.7 & 6.7 & 6.6 & 5.6 \\
\hline$\Delta_{(95 \%)}$ & 0.1 & 0.1 & 0.2 & 0.1 & 0.3 & 0.1 & 0.2 \\
\hline $9-10$ years & 4.8 & 4.3 & 3.9 & 4.7 & 4.8 & 5.1 & 4.7 \\
\hline$\Delta_{(95 \%)}$ & 0.1 & 0.1 & 0.4 & 0.3 & 0.5 & 0.2 & 0.3 \\
\hline $11-12$ years & 6.7 & 6.2 & 6.1 & 6.4 & 6.7 & 7.2 & 5.2 \\
\hline$\Delta_{(95 \%)}$ & 0.2 & 0.2 & 0.3 & 0.2 & 0.4 & 0.2 & 0.3 \\
\hline $13-14$ years & 8.4 & 8.2 & 7.4 & 8.2 & 8.8 & 8.3 & 7.3 \\
\hline$\Delta_{(95 \%)}$ & 0.2 & 0.1 & 0.2 & 0.2 & 0.6 & 0.3 & 0.4 \\
\hline $15-16$ years & 9.4 & 9.1 & 8.7 & 9.0 & & & \\
\hline$\Delta_{(95 \%)}$ & 0.1 & 0.1 & 0.2 & 0.2 & & & \\
\hline
\end{tabular}

aSee previous comment on interpretation of the 'all' figure.

Table 8. Literacy and safety skills (only 11+).

\begin{tabular}{llllllll}
\hline $\begin{array}{l}\text { Average } \\
\text { number of } \\
\text { skills }\end{array}$ & $\begin{array}{l}\text { Only } \\
\text { child }\end{array}$ & $\begin{array}{l}\text { Has } \\
\text { younger } \\
\text { sibling/s }\end{array}$ & $\begin{array}{l}\text { Has similar age } \\
\text { and younger } \\
\text { siblings }\end{array}$ & $\begin{array}{l}\text { Has similar } \\
\text { age sibling/s }\end{array}$ & $\begin{array}{l}\text { Has similar } \\
\text { age and older } \\
\text { siblings }\end{array}$ & $\begin{array}{l}\text { Has older } \\
\text { sibling/s }\end{array}$ & $\begin{array}{l}\text { Has both } \\
\text { younger and } \\
\text { older siblings }\end{array}$ \\
\hline All & 4.3 & 4.3 & 4.1 & 4.3 & 3.4 & 3.6 & 2.9 \\
$\Delta_{(95 \%)}$ & 0.1 & 0.1 & 0.1 & 0.1 & 0.2 & 0.1 & 0.2 \\
$11-12$ years & 2.9 & 2.7 & 2.7 & 2.8 & 3.0 & 3.0 & 2.3 \\
$\Delta_{(95 \%)}$ & 0.1 & 0.1 & 0.2 & 0.2 & 0.3 & 0.1 & 0.2 \\
$13-14$ years & 4.4 & 4.2 & 4.2 & 4.5 & 4.2 & 4.5 & 3.7 \\
$\Delta_{(95 \%)}$ & 0.1 & 0.1 & 0.2 & 0.1 & 0.4 & 0.2 & 0.3 \\
$15-16$ years & 5.3 & 5.5 & 4.9 & 5.0 & & & \\
$\Delta_{(95 \%)}$ & 0.1 & 0.1 & 0.2 & 0.1 & & & \\
\hline
\end{tabular}

${ }^{a}$ See previous comment on interpretation of the 'all' figure.

self-protective online behaviours. These included eight areas of competency such as being able to bookmark a website, through to blocking messages from someone that a child does not want to hear from (see list, Livingstone et al., 2011a: 28). This was one of the areas of questioning that was dropped for the 9- to 10-year-old survey in acknowledgement of their shorter attention and concentration spans, and in an effort to keep the interview/survey at an age-appropriate length. One of the clearest indications from these data is that children with both older and younger siblings are consistently less likely than children with other sibling constellations to say that they have these digital 
literacy and safety skills, to the extent that children from this cohort are the only 13- to 14year-old group not to have mastered at least half of the literacy and safety skills investigated (Table 8). It is difficult to hypothesise why this might be. Even so, notwithstanding previous correlations, it may be that members of families with three or more children are comparatively time poor, have social and emotional opportunities and responsibilities that compete with online activities, and these children may have access to fewer digital resources and greater competition for the resources that they have.

Table 9. Percentage of children who have encountered one or more of the risks investigated.

\begin{tabular}{|c|c|c|c|c|c|c|c|}
\hline $\begin{array}{l}\text { \% Have } \\
\text { encountered one } \\
\text { or more risks }\end{array}$ & $\begin{array}{l}\text { Only } \\
\text { child }\end{array}$ & $\begin{array}{l}\text { Has } \\
\text { younger } \\
\text { sibling/s }\end{array}$ & $\begin{array}{l}\text { Has similar } \\
\text { age and } \\
\text { younger } \\
\text { siblings }\end{array}$ & $\begin{array}{l}\text { Has similar } \\
\text { age } \\
\text { sibling/s }\end{array}$ & $\begin{array}{l}\text { Has similar } \\
\text { age and } \\
\text { older } \\
\text { siblings }\end{array}$ & $\begin{array}{l}\text { Has older } \\
\text { sibling/s }\end{array}$ & $\begin{array}{l}\text { Has both } \\
\text { younger and } \\
\text { older } \\
\text { siblings }\end{array}$ \\
\hline$\overline{\text { Alla }^{a}}$ & 42 & 41 & 47 & 45 & 34 & 30 & 26 \\
\hline$\Delta P_{(95 \%)}$ & 1.0 & 1.1 & 2.5 & 1.7 & 4.7 & 1.7 & 3.2 \\
\hline $9-10$ years & 14 & 10 & 11 & 14 & 20 & 16 & 16 \\
\hline$\Delta P_{(95 \%)}$ & 1.4 & 1.3 & 4.6 & 3.6 & 8.1 & 2.3 & 4.3 \\
\hline $11-12$ years & 33 & 31 & 30 & 36 & 38 & 32 & 32 \\
\hline$\Delta P_{(95 \%)}$ & 2.0 & 2.2 & 4.7 & 3.5 & 7.2 & 3.0 & 5.6 \\
\hline $13-14$ years & 51 & 51 & 45 & 47 & 43 & 52 & 33 \\
\hline$\Delta P_{(95 \%)}$ & 2.0 & 2.4 & 4.8 & 3.6 & 9.0 & 3.6 & 6.9 \\
\hline 15-16 years & 65 & 61 & 67 & 59 & & & \\
\hline$\Delta P_{(95 \%)}$ & 1.8 & 2.4 & 4.0 & 2.6 & & & \\
\hline
\end{tabular}

${ }^{a}$ See previous comment on interpretation of the 'all' figure.

\section{Sibling differences in online risk and harm}

In addition to the access to technology, opportunities to spend time online and the possession of skills and competencies outlined above, we also wanted to find out (RQ2) whether and how sibling status influences children's experiences with online risks and risk of harm. Surveyed children were asked about their exposure to a specific set of online risks over the previous 12 months: whether they had seen sexual images online or offline, whether they had been bullied (if someone had acted in a nasty or hurtful way towards them in the past 12 months), whether other people had misused their personal data, whether they had sent or received sexts, whether they had met up offline with someone that the child had got to know only through online activities, and whether they had accessed troubling user-generated content (such as suicide support sites and anorexia sites). Coverage of the overall findings in relation to experiences of risk and harm is discussed in Livingstone et al. (2011a: 133-135), and a majority of children surveyed had not encountered any of these risks in the previous year. Where children had experienced one or more risks, this was then calculated in relation to sibling constellation.

Table 9 shows the sibling differences in six online risk experiences (sexual images, bullying, misuse of personal data, the child meeting in person someone who is known online but who is otherwise a stranger, sexting and user-generated content).

Other research has demonstrated that older children are more likely to be risk-taking and sensation-seeking than younger ones, and that this is also truer of boys than of girls. Thus, teenage boys are far more likely to engage in experiences which bring them into contact with online risk than are their younger sisters. The risk of harm may be greater for 
the younger sister, however, since a child's capacity to cope with risky experiences develops with age. One indication of this dynamic relates to the EU Kids Online research around encounters with online sexual content (Livingstone et al., 2011a: 57). As Livingstone et al. (2011a) note (p. 58), 'those who encounter most risk online (often, teenagers, boys) are not necessarily those most bothered or upset by the experience (often, younger children, girls)'.

Table 10. Children who say they have been bothered by something on the Internet over the past 12 months.

\begin{tabular}{llllllll}
\hline $\begin{array}{l}\text { \% Have been } \\
\text { bothered by } \\
\text { something }\end{array}$ & $\begin{array}{l}\text { Only } \\
\text { child }\end{array}$ & $\begin{array}{l}\text { Has } \\
\text { younger } \\
\text { sibling/s }\end{array}$ & $\begin{array}{l}\text { Has similar age } \\
\text { and younger } \\
\text { siblings }\end{array}$ & $\begin{array}{l}\text { Has similar } \\
\text { age } \\
\text { sibling/s }\end{array}$ & $\begin{array}{l}\text { Has similar } \\
\text { age and older } \\
\text { sibling/s }\end{array}$ & $\begin{array}{l}\text { Has older } \\
\text { sibling/s }\end{array}$ & $\begin{array}{l}\text { Has both } \\
\text { younger and } \\
\text { older siblings }\end{array}$ \\
\hline All & 10 & 13 & 14 & 13 & 7 & 12 & 8 \\
$\Delta P_{(95 \%)}$ & 0.6 & 0.8 & 1.8 & 1.2 & 2.5 & 1.2 & 1.9 \\
$9-10$ years & 8 & 9 & 7 & 13 & 8 & 12 & 10 \\
$\Delta P_{(95 \%)}$ & 1.1 & 1.2 & 3.7 & 3.5 & 5.5 & 2.0 & 3.4 \\
$11-12$ years & 9 & 11 & 11 & 14 & 6 & 12 & 8 \\
$\Delta P_{(95 \%)}$ & 1.3 & 1.5 & 3.1 & 2.5 & 3.5 & 2.1 & 3.2 \\
$13-14$ years & 11 & 12 & 16 & 13 & 7 & 11 & 4 \\
$\Delta P_{(95 \%)}$ & 1.3 & 1.5 & 3.5 & 2.4 & 4.7 & 2.2 & 3.0 \\
$15-16$ years & 13 & 18 & 17 & 14 & & & \\
$\Delta P_{(95 \%)}$ & 1.2 & 1.9 & 3.2 & 1.8 & & & \\
\hline
\end{tabular}

aSee previous comment on interpretation of the 'all' figure.

When we examine the data that might indicate the additional risk posed to the younger ones by having an older brother sibling, it appears that it might be the 'similar age' and 'similar age and older' siblings that pose the greater risk to the 9- to 10-year-olds and 11to 12 -year-olds, but the 13- to 14-year-old and 15- to 16-year-old results are less clear cut with no apparent sibling-related pattern. Once again, this might reflect the growing influence of peers in this age group and a comparative decline in the influence of older siblings once the child in question has reached their teens.

Children were asked not only about the risks they had experienced in the previous 12 months, but also about whether those experiences had bothered them. There were no necessary assumptions made about content that might have bothered children. Prior to prompting information about specific risks investigated, children were asked a general question about their experiences online: In the past 12 months, have you seen or experienced something on the Internet that has bothered you in some way? Within Europe, 12\% of children said that they had been bothered by something online in the previous year. These data were then examined in terms of sibling constellations (Table 10).

Once again, the picture seems to differ according to the age group of the target child. In the 9- to 10-year-old and 11- to 12-year-old age groups, it seems that having similar aged siblings might be associated with an increased likelihood of being bothered by something online during the previous year. For the 13- to 14-year-old and 15- to 16-yearold age groups, it seems that it is similar aged and younger siblings who are associated with the risk of feeling bothered. This is difficult to understand given older children's greater resilience in the face of exposure to challenging online content, unless it is their concern about younger siblings' vulnerabilities that may be feeding into older children's experiences of feeling bothered. Although the average percentage of 'botherment' across the national populations of children responding to this research was $12 \%$, the proportion of children saying this rises with age (9-10 years, $9 \%$; $11-12$ years, $11 \%$; $13-14$ years, $12 \%$; $15-$ 16 years, 15\%: Livingstone et al., 2011a: 46), which is also in line with expected exposure to risk. Sole children are also less likely than children with siblings to say that they have felt 
bothered. It may be that older children $(13+)$ with younger siblings feel bothered because of experiences shared with the younger child, or feelings of responsibility. Qualitative research is needed to understand this dynamic better.

Table 11. Logistic regression models for the probability of children using the Internet daily and for having encountered one or more of six risks.

\begin{tabular}{lllll}
\hline & Daily use & & Risks & \\
\cline { 2 - 5 } & $\operatorname{Exp}(b)$ & Sig. & $\operatorname{Exp}(b)$ & Sig. \\
\hline Constant & 1.87 & .00 & 0.33 & .00 \\
Has younger sibling(s) & 0.84 & .00 & 0.96 & .15 \\
Has similar age sibling(s) & 0.94 & .08 & 0.99 & .72 \\
Has older sibling(s) & 1.17 & .00 & 0.95 & .24 \\
Age & 1.45 & .00 & 1.40 & .00 \\
Age $\times$ younger sibling(s) & 0.98 & .08 & 1.03 & .02 \\
Age $\times$ similar age sibling(s) & 0.95 & .00 & 0.96 & .03 \\
Age $\times$ older sibling(s) & 0.99 & .69 & 0.96 & .13 \\
Daily use & & & 2.72 & .00 \\
Chi-square & 3141 & & 5182 & \\
df & 7 & & 8 & \\
-2 Log likelihood & 29,135 & & 29,140 & \\
Cox and Snell $R^{2}$ & 0.12 & & 0.19 & \\
Nagelkerke $R^{2}$ & 0.16 & & 0.25 & \\
\hline
\end{tabular}

\section{Sibling differences in online opportunities and risks}

Finally, we wanted to see (RQ3) whether and how sibling status can predict online opportunities and risks. For both risks and opportunities, the effect of siblings seems to be dependent on age. This can be further explored by multivariate analysis. We look at the data on daily Internet use (see also Table 3) as a measurement of opportunities, and as indicating the likelihood of encountering one of six defined risks (as shown in Table 9) - a general measurement of risk. When looking at risks, we include daily Internet use also as a predictor. As observed in the previous tables, sibling status has a different effect for children of different ages, and therefore, we include both the main effects for age and sibling status, and interaction terms for difference in sibling effects by age (Table 11).

Both opportunities and risks increase with age. On average, the probability of using the Internet daily increases by $45 \%$ for each year a child grows older, and the likelihood of encountering at least one type of risk increases by $40 \%$. To demonstrate how the age and sibling interaction works, we present here two figures showing the predicted probability of, on the one hand, the likelihood of a child using the Internet daily (Figure 1), as a proxy for online opportunities and, on the other hand, the likelihood of a child encountering one or more of six risks (RQ3). Both figures emphasise again the importance of age when it comes to explaining differences in use and risks. For daily use, the biggest difference is between those children who have an older sibling (related to higher use) and those who have a younger sibling (related to lower use). For risks, the sibling effects are different for children of different age. For the younger children, the presence of a younger sibling is thus related to a slight reduction in risks, whereas for older children having a younger sibling, it can be related to a slight increase in risks (Figure 2). 


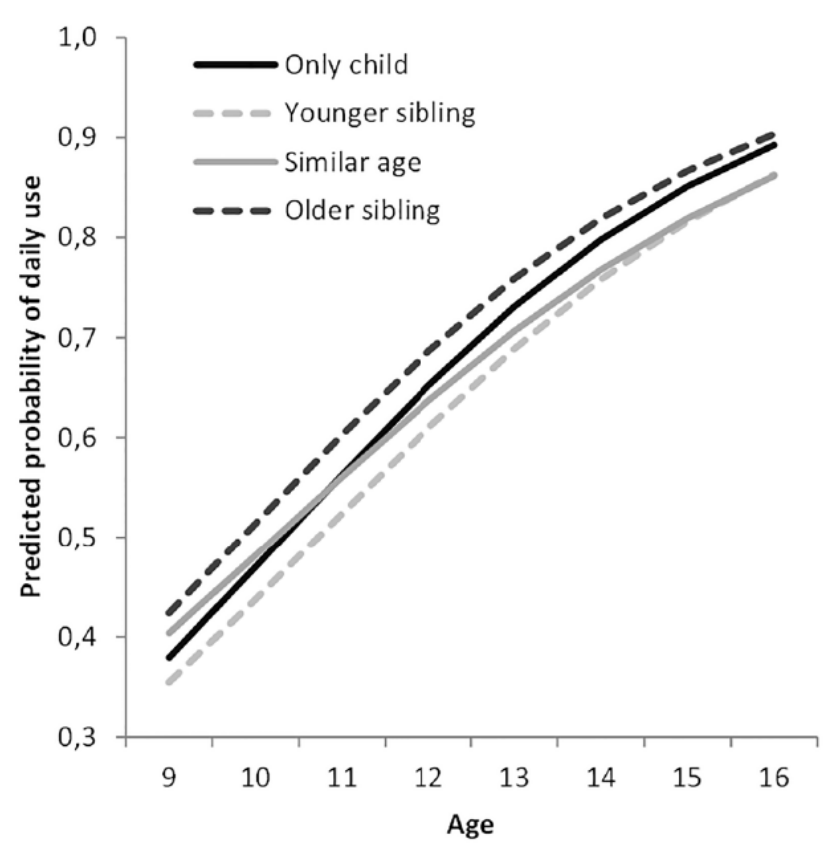

Figure 1. Predicted probability of using the Internet daily by sibling status.

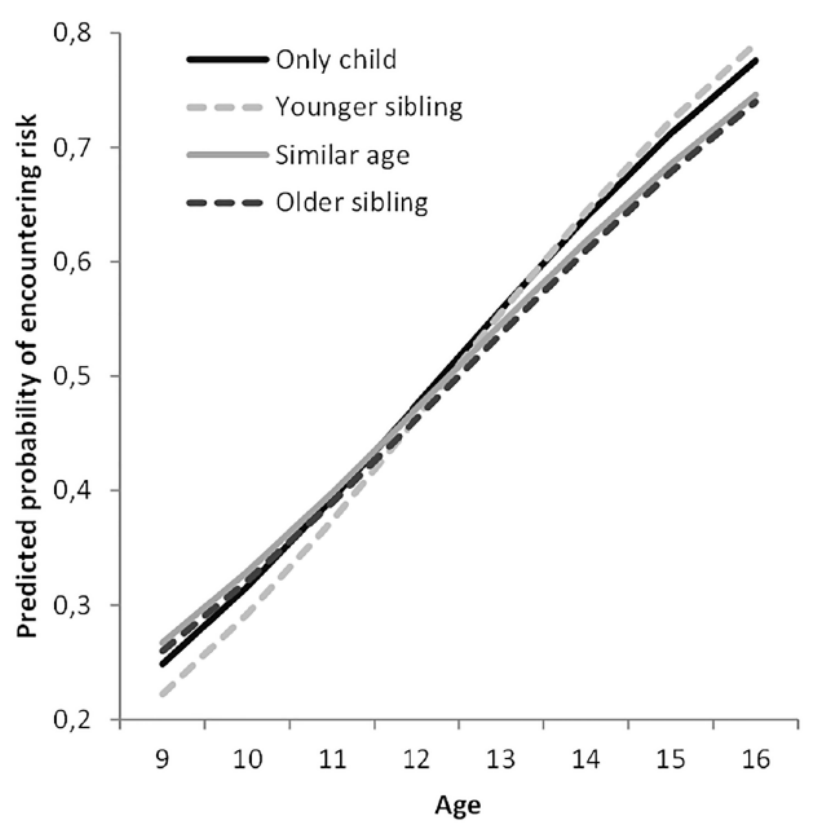

Figure 2. Predicted probability of encountering one of six risks by sibling status.

\section{Conclusion}


So, what effects do siblings have? Sibling effects as observed in our data are small. The reason for this might be that it is difficult to differentiate these effects from those caused by other processes in the family. In this respect, we do not have, for example, a measurement for the quality of relationships between the siblings. Nor do we have a way of indicating whether the siblings are of the same or different genders. But we do see that in terms of use and opportunities, the presence of older siblings seems to slightly increase use, whereas the presence of younger siblings is correlated with a slight reduction. This impact is most visible in the use of SNSs.

As for children's online use, activities and skills online (RQ1), our results show how having siblings seems to put some limitations on access, perhaps caused by competing with siblings to use a device, and this might limit the time spent online. Having older siblings increases the number of online activities claimed, possibly through additional support in skill development, and that perhaps compensates to some extent for the reduced access.

The results in terms of risks and harm (RQ2) are not straightforward and merit further research. For risks, the age interactions are more nuanced, so for younger children, the presence of younger siblings can be associated with a slight reduction in the probability of encountering risks, whereas for older children, the presence of a younger sibling can be related to a slight increase in risks. For younger children, the presence of an older sibling is NOT, it seems, associated with any increase in risks.

Our findings merit further, and more targeted, research on how sibling constellations influence opportunities, risks and parental mediation practices. Although the data used in this study were gathered over the course of 2010 and first analysed in 2011, this recent secondary analysis of the 25,142-child database remains the best evidence available for enquiring into levels of online risk exposure, opportunity experience and coping strategies among children in sibling relationships. It also provides guidance for future research trajectories, particularly in terms of qualitative investigations which have the potential to explain the dynamics at work in these complex family relationships.

Yet, the dataset has limitations. For instance, we do not know how recent technological developments and changes in usage patterns might influence sibling relationships at home. Since 2010, the rapid development in mobile technologies and the extended use of both smartphones and free-to-take-anywhere tablets have made children's online activities at home less fixed, not bound to specific locations. This might influence the opportunities children have around deciding whether or not to be co-present with their siblings when they go online at home. Also, further research is needed to investigate how differences in culture might influence sibling relationships and media use.

Researching whether and how sibling status can predict online opportunities and risks, we know that the EU Kids Online data clearly link these aspects to age and gender, establishing that younger children are less likely to encounter risk, but they are more likely to feel bothered if they do so (Livingstone et al., 2011a: 57). So, extrapolating from this and from our research, big brother will be far more likely to experience online risk than his younger sister, but it is his younger sister who is most likely to be bothered by the risks she encounters.

\section{Acknowledgements}

The authors would like to thank the anonymous reviewers for valuable feedback on an earlier version of this article. We also thank Dag Grytli for research assistance.

\section{Funding}


This article draws on the work of the EU Kids Online network funded by the European Commission (EC) (DG Information Society) Safer Internet Programme (project code SIP-KEP321803); see http://www.eukidsonline.net. Lelia Green's participation was partly funded by an Australian Research Council Discovery Grant DP110100864 'Parents or peers: which group most affects the experiences of young people online, and how?'

\section{References}

Caverly SL (2006) The contribution of siblings to children's social competence. PhD Thesis, George Mason University, Ann Arbor, MI.

Coyne SM, Archer J and Eslea M (2006) 'We're not friends anymore! Unless ...': the frequency and harmfulness of indirect, relational, and social aggression. Aggressive Behavior 32: 294-307.

Duerager A and Livingstone S (2012) How Can Parents Support Children's Internet Safety? London: EU Kids Online, LSE.

Farrugia L and Haddon L (2014) Mediation by siblings and other relatives. In: Smahel D and Wright MF (eds) The Meaning of Online Problematic Situations for Children. London: EU Kids Online, London School of Economics and Political Science, pp. 137-139. Available at: http://eprints.lse.ac.uk/56972/

Green L and Haddon L (2015) Parents' reflections upon mediating older teens' gaming practices. In: Cammaerts B, Anstead N and Garland R (eds) Media@LSE Working Paper Series. Available at: http://www.lse.ac.uk/media@lse/research/mediaWorkingPapers/pdf/WP37-FINAL.pdf

Howe N and Recchia H (eds) (2014) The sibling relationship as a context for learning and development. Early Education and Development (Special issue) 25: 155-275.

Howe N, Della Porta S, Recchia H, et al. (2016) 'Because if you don't put the top on, it will spill': a longitudinal study of sibling teaching in early childhood. Developmental Psychology 52: 1832-1842.

Jenson JM and Fraser MW (2016) A risk and resilience framework for child, youth and family policy. In: Jenson JM and Fraser MW (eds) Social Policy for Children and Families: A Risk and Resilience Perspective. 3rd ed. Thousand Oaks, CA: SAGE, pp. 5-24.

Kaare BH, Brandtzæg PB, Heim J, et al. (2007) In the borderland between family orientation and peer culture: the use of communication technologies among Norwegian tweens. New Media \& Society 9: 603-624.

Livingstone S (2008) Taking risky opportunities in youthful content creation: teenagers' use of social networking sites for intimacy, privacy and self-expression. New Media \& Society 10: 393-411.

Livingstone S, Haddon L and Görzig A (2012) Children, Risk and Safety on the Internet. Bristol: Policy Press.

Livingstone S, Haddon L, Görzig A, et al. (2011a) Risk and Safety on the Internet: The Perspective of European Children - Full Findings from the EU Kids Online Survey of 9-16 Year Olds and Their Parents. London: EU Kids Online, LSE.

Livingstone S, Haddon L, Görzig A, et al. (2011b) Technical report and user guide: the 2010 EU Kids Online survey. A report on the design and implementation of the EU Kids Online survey of 9-16 year olds and their parents in 25 countries, LSE, London.

Mascheroni G, Vincent J and Jimenez E (2015) 'Girls are addicted to likes so they post semi-naked selfies': peer mediation, normativity and the construction of identity online. Cyberpsychology: Journal of Psychosocial Research on Cyberspace 9(1): Article 5.

Meunier JC, Boyle M, O’Connor TG, et al. (2013) Multilevel mediation: cumulative contextual risk, maternal differential treatment, and children's behaviour within families. Child Development 85: $1594-1615$.

Milevsky A (2011) Sibling Relationships in Childhood and Adolescence: Predictors and Outcomes. New York: Columbia University Press.

Minnett AM, Vandell DL and Santrock JW (1983) The effects of sibling status on sibling interaction: influence of birth order, age spacing, sex of child, and sex of sibling. Child Development 54: 1064 1072.

Robinson L and Schulz J (2013) Net time negotiations within the family. Information, Communication and Society 16(4): 542-560

Sanders R (2004) Sibling Relationships: Theory and Issues for Practice. Basingstoke: Palgrave Macmillan.

Šmahel D, Helsper E, Green L, et al. (2012) Excessive Internet Use among European Children. EU Kids Online, LSE. Available at: 
http://www2.lse.ac.uk/media@1se/research/EUKidsOnline/EU\%20Kids $\% 20 \mathrm{III} /$ Reports/Excessi veUse.pdf

Staksrud E and Ólafsson K (2013) Awareness: strategies, mobilisation and effectiveness. In: O’Neill B, Staksrud E and McLaughlin S (eds) Towards a Better Internet for Children? - European Policy Pillars, Players and Paradoxes. Göteborg: Nordicom, pp. 57-76.

Suess D, Suoninen A, Garitaonandia C, et al. (1998) Media use and the relationship of children and teenagers with their peer groups. European Journal of Communication 13: 521-538.

Suoninen A (2001) The role of media in peer group relations. In: Livingstone SM and Bovill M (eds) Children and Their Changing Media Environment: A European Comparative Study. Mahwah, NJ: Lawrence Erlbaum Associates, pp. 201-219.

Vandoninck S, d'Haenens L, De Cock R et al. (2011) Social networking sites and contact risks among Flemish youth. Childhood 19(1): 69-85

\section{Author biographies}

Kjartan Ólafsson is a lecturer and head of department og social sciences and law at the University of Akureyri in Iceland. He has played a key role in the design and implementation of a number of cross national research projects on children's media use. Amongst these is the 2010 EU Kids Online study which has been a landmark project in the field of media studies in Europe.

Lelia Green is Professor of Communications, School of Arts and Humanities, Edith Cowan University, Perth, Australia. She is the author of The Internet: An Introduction to New Media (Berg, 2010). Lelia's work with the EU Kids Online project has been supported by a number of Australian Research Council projects examining children's lives online.

Elisabeth Staksrud, $\mathrm{PhD}$, is an Associate Professor at the Department of Media and Communication, University of Oslo, researching online censorship, and children's rights and risks. She is also Deputy Chair of the Norwegian National Committee for Research Ethics in the Social Sciences and the Humanities (NESH) and part of the management team of EU Kids Online. 